\title{
PASAR MU'AMALAH DAN REKONSTRUKSI \\ PENGGUNAAN DINAR, DIRHAM DAN FULUS SEBAGAI ALAT TUKAR DI CIREBON
}

\author{
Zaenal Masduqi dan Alvien Septian Haerisma \\ Institut Agama Islam Negeri Syekh Nurjati Cirebon \\ Email: zaenalmasduqi85@yahoo.com danalvienseptian@gmail.com
}

\begin{abstract}
The dinar and dirham transaction system has been known for a long time in Indonesia, but not many people are aware of using the dinar and dirham as a transaction tool. In the field of muamalah market, many Muslims do not know or even care that Islam has a powerful and comprehensive set of values and rules when understood and implemented. This is motivated because there are not many Islamic scholars and community leaders who socialize the theory and practice of Islamic trade, in addition to submitting the values and rules of Islamic trade to the interests of the global capitalist economy.This transaction media is accommodated by the mu'amalah market using a market system and in economic activities it refers to the concept of benefit and upholds the principles of justice. This can be seen from the current number of dinar and dirham traders and users in the mu'amalah market trading network which has been developing since its inception in 2009 until today. This study aims to photograph the practice of the Islamic trading system and its benefits through the mu'amalah market with dinar, dirham and fullus exchange based on waqf land.
\end{abstract}

Keywords: Mu'amalah Market, Medium of Exchange, Waqf, Global Capitalist.

\begin{abstract}
Abstrak
Sistem transaksi dinar dan dirham sudah dikenal cukup lama di Indonesia, akan tetapi belum banyak masyarakat yang sadar untuk menggunakan dari dinar dan dirham sebagai alat transaksi. Dalam bidang pasar mu'amalah banyak dari kaum muslimin tidak tahu bahkan tidak memperdulikan bahwa Islam memiliki seperangkat nilai dan aturan yang dahsyat dan komprehensif bila difahami dan dilaksanakan. Hal ini dilatarbelakangi karena tidak banyak dari ulama dan tokoh masyarakat Islam yang mensosialisasikan teori dan praktek perdagangan secara Islam, disamping tertunduknya nilai dan aturan perdagangan Islam itu kepada kepentingan ekonomi kapitalis global.Media transaksi ini diwadahi oleh pasar mu'amalah dengan menggunakan sistem pasar danpada kegiatan ekonomi itu mengacu kepada konsep maslahat dan menjunjung tinggi asas-asaskeadilan. Hal ini dapat dilihat dari jumlah pedagang dan pengguna dinar dan dirham saat ini pada jaringan perdagangan pasar mu'amalah yang pada perkembangan dari awal dibentuk pada tahun 2009 sampai dengan saat ini. Penelitian ini bertujuan memotret praktek sistem perdagangan Islam beserta manfaat-manfaatnya melalui pasar mu'amalah dengan alat tukar dinar, dirham dan fullus berbasis tanah wakaf.
\end{abstract}

Kata Kunci: Pasar Mu'amalah, Alat Tukar, Wakaf, Kapitalis Global. 


\section{PENDAHULUAN}

Islam adalah sebuah agama dengan seperangkat ajaran dan piranti yang kompherehnsif mengantarkan segenap pemeluknya untuk sukses meniti karir kehidupan dunia akhirat. Dalam kehidupan dunia diajarkan kepada umatnya bagaimana bisa mengatasi hidup dan kehidupan dengan memiliki sumber mata pencaharian yang dinamis dan mandiri. Salah satunya dengan mengenal dan menguasasi perdagangan sebagai salah satu ornamen yang paling penting dari sistem perdagangan adalah pasar yang tersedia secara aman dan nyaman.

Adanya pasar bagi pedagang adalah serupa dengan ketersediaan jalan bagi setiap orang untuk berjalan dan bepergian, sekolah untuk belajar dan musholla untuk sholat. Tanpa pasar orang tak bebas untuk berdagang, baik sendiri-sendiri maupun dalam kafilah-kafilah dagang dari satu pasar terbuka ke pasar terbuka lainnnya. Bahkan pasar-pasar tersebut bergerak yang dicerminkan dari namanya, seperti; Suqul Ahad di Damaskus, Suqul Tulatha di Baghdad, Suqul Arba'a di Maswil dan Suqul Khamis di Fes dan Marakesh. Dahulu nenek moyang Bangsa Indonesia pun menjalankannya, seperti Pasar Senen, Pasar Rebo, Pasar Kamis, Pasar Jum 'at, dan Pasar Minggu. Sementara di Jawa kita kenal dengan Pasar Pahing, Pasar Pon, Pasar Wage, Pasar Kliwon dan Pasar Legi. (Zaim Saidi, 2011). Nama-nama pasar yang tersebut di atas dimaknai sebagai tempat atau lingkungan berbagai komoditas yang diperjaulbelikan

Pasar yang selama ini berjalan di Indonesia hanya bertujuan agar upaya pemaksimalan untuk mencari untung yang sebesar-besarnya dan cenderung fokus pada kepentingan sendiri. Sistem tersebut nampaknya kurang baik untuk diterapkan dengan sistem ekonomi syariah yang menekankan konsep manfaat yang lebih besar pada kegiatan ekonomi termasuk di dalamnya sistem pasar dan pada kegiatan ekonomi itu mengacu kepada konsep maslahat dan menjunjung tinggi asas-asas keadilan (Islam dan Fajar, 2020).

Rujukan pertama dalam konteks pasar terbuka atau yang kemudian kita menamakannya dengan pasar mu'amalah adalah sikap Rasulullah Shallallahu 'alaihi wa sallam dalam membangun pasar pertama di Madinah dengan nama Baqi' al-Zubayr yang sepenuhnya merupakan lapangan terbuka tanpa bangunan permanen dan dekat dengan masjid, sehingga bila adzan sholat berkumandang maka bergegaslah para pembeli dan penjual menuju masjid. (Film The Massage, 1976).

Kondisi yang demikian tersebut berdampak positif terhadap perekonomian, khususnya memulihkan kondisi finansial kaum Muhajirin sebagai pedagang dan pekerja, juga menguntungkan kaum Anshor yang petani dan peternak. Dengan bangkitnya perekonomian umat maka terbuka manfaat yang lebih besar lagi seperti membesarkan zakat, infak, sedekah dan membelanjakan harta untuk fi sabilillah, sebagai bukti dari keberhasilan tersebut pada tahun $2 \mathrm{H}$, Rasulullah dan para sahabat telah mampu membiayai perang Badar (Masduqi, 2012).

Terkait dengan keberlangsungan pasar tersebut keberadaan institusi wakaf dan penggunaan koin perak (Dirham) dan koin tembaga (Fulus) serta pembagian zakat menjadi perhatian utama dalam kajian ini, sebagai upaya rekonstruksi masa lalu yang pernah terlintas dalam perjalanan sejarah umat Islam dan bangsa Indonesia. Sekaligus sebagai bentuk nyata dari konsep Islam tentang pasar dan implikasi yang ditimbulkannya. Di Indonesia sendiri beberapa komunitas kecil muslim sudah menerapkan pembayaran transaksi perdagangan dengan pasar yang disediakan menggunakan dengan alat tukar dinar, dirham dan fulus di samping Rupiah. Bahkan koin emas atau uang dinar dan dirham yang penggunanya tidak terbatas di kalangan muslim saja.

Masyarakat muslim sekarang, faktanya banyak belum memahami sejarah 
dan penggunaan fungsi uang dari dinar, dirham dan fulus. Seharusnya sudah diketahui tentang pemahaman tersebut. Sedikitnya peran Ulama, tokoh masyarakat dan ilmuwan yang mendorong terciptanya proses transaksi dinar, dirham dan fulus. Hal ini disebabkan kurangnya ghirah (semangat) dalam menjalankan mu'amalah maliyah yang berkaitan transaksi dinar, dirham dan fulus.

Berpijak pada urgensi yang tercermin dalam al-Qur'an bahwa emas sebagai nilai standar salah satunya dalam perhitungan zakat. Emas bukan hanya dalam nash, melainkan nilai sunnah yang wajib kita yakini. Pada prinsipnya, kita bersepakat bahwa hukum Islam mempunyai sifat fleksibel, karena dalil-dalil dasar menetapkan bahwa permasalahan yang ada di sekitar kita (didunia) ini sekalipun akan berakhir, tapi ia tidak keluar dari jalur yang dinamakan prinsip-prinsip dasar yang telah ditetapkan. Hal ini dapat dijadikan sebuah solusi terbaik guna menuju perekonomian yang lebih makmur (Haerisma, 2011).

Dari penjabaran singkat seperti yang diuraikan dalam latar belakang, maka penulis mencoba simpulkan beberapa pertanyaan; pertama, Bagaimana konsep dan praktek Pasar Mu'amalah? kedua, Apa saja manfaat yang ditimbulkan dari keberadaan Pasar Mu'amalah? Dan ketiga, Apa kaitannya dengan institusi wakaf dalam transaksi dinar, dirham dan fulus?.

\section{LITERATURE REVIEW}

Penelitian terdahulu digunakan untuk membantu mendapatkan gambaran dalam menyusun mengenai penelitian ini. Adapun penelitian terdahulu yang telah membahas topik ini, yaitu :

Pertama Jurnal Bintang Islam dan Muhamad Fajar yang berjudul Perancangan Infografis Pasar Muamalah Sebagai Awal Kembalinya Dinar Dirham. Adapun pembahasan yang diangkat Pasar Muamalah menjadi pasar yang menerapkan nilai nilai syariah di dalamnya. Dengan menggunakan uang dinar dirham dalam setiap transaksinya, menegaskan adanya akad jual beli, menghindarkan jual beli dari praktik riba karena nilai dinar dirham relatif stabil sepanjang zaman sehingga tidak terjadi penyusutan nilai tukar. Kegiatan Muamalah dalam bidang perdagangan merupakan suatu potensi yang memberikan peluang yang besar terhadap kemajuan dan perkembangan umat Islam. Oleh karena itu dibutuhkan media informasi yang berisi keunggulan pasar Muamalah yang menggunakan dinar dirham dengan pasar biasa yang menggunakan uang kertas dan koin (Islam dan Fajar, 2020).

Kedua, Thesis Danang Handir Gantoro, Universitas Islam Indonesia, Yogyakarta,2020 yang berjudul Model Usaha Pasar Muamalah Dinar dan Dirham di Yogyakarta. Thesis ini berisi tentang keberadaan pasar muamalah dapat menjadi salah satu media untuk kembali menggunakan dinar dan dirham sebagai alat transaksi. Salah satu pasar muamalahdi Yogyakarta yaitu di Emfa Pasar Muamalah. Keberadaan pasar muamalah adalah pasar tradisional yang jarang ditemui, adanya pasar ini ditujukan dengan maksud menghidupkan sunnah dalam pasar. Oleh karena itu perkembangan jalannya pasar muamalah layak untuk diamati. Tujuan penelitian ini meliputi: (1) Mengetahui model usaha pasar muamalah Dinar dan Dirham di Yogyakarta; (2) Mengetahui penerapan prinsip-prinsip muamalah di pasar muamalah Yogyakarta; dan (3) Mengetahui sistem pengawasan pasar muamalah Dinar dan Dirham di Yogyakarta (Gantoro, 2009).

Ketiga, penelitian skripsi oleh Anif Nur Isnaini dan Yayuli yang berjudul Penerapan Konsep Pasar Islam Era Rasulullah Perspektif Zaim Saidi (Studi Pasar Muamalah Surakarta), Universitas Muhammadiyah Surakarta, 2021. Ada tiga poin utama yang menjadi fokus penelitian, yaitu: penerapan indikator atau Sunnah Pasar Syariah, konsep al-Hisbah atau pengawasan pasar, dan larangan intervensi harga. analisis di atas, dapat disimpulkan bahwa Pasar Muamalah Surakarta telah melaksanakan 
tiga poin utama penelitian dengan baik. Indikator Islamic Market adalah: pasar yang mirip dengan masjid, tidak ada kepemilikan pribadi, tidak ada pajak dan biaya sewa, tidak ada klaim/pemesanan tempat, tidak ada penghalang atau toko di pasar, diterapkan dengan baik di Pasar Muamalah Surakarta. Koordinator Pasar Muamalah Surakarta selain sebagai ketua pasar, juga menjabat sebagai al-muhtasib atau pengawas pasar. Selain itu, tidak adanya kebijakan intervensi harga barang di Pasar Muamalah Surakarta. Harga barang ditetapkan berdasarkan kesepakatan antara pembeli dan penjual (Isnaini dan Yayuli, 2021).

Keempat, penelitian skripsi oleh Nispi Amalia Adila yang berjudul Penggunaan Dinar dan Dirham Sebagai Alat Transaksaksi di Pasar Muamalah Indonesia: Analisis Pengaruh Faktor Sosial, Faktor Kecemasan, Faktor Religiositas, dan Faktor Kepercayaan, Universitas Pendidikan Indonesia, 2020. Hasil penelitian dalam kajian ini menunjukkan bahwa tingkat lingkungan sosial ada pada kategori sedang, tingkat kecemasan pada kategori rendah, tingkat religiositas dan tingkat kepercayaan pada otoritas penerbit ada pada kategori tinggi. Terdapat tiga variabel yang berpengaruh positif signifikan terhadap penggunaan dinar dan dirham sebagai alat transaksi di Pasar Muamalah Indonesia yakni tingkat lingkungan sosial, tingkat religiositas dan tingkat kepercayaan pada otoritas penerbit. Sedangkan untuk variabel tingkat kecemasan tidak berpengaruh dan tidak signifikan terhadap penggunaan dinar dan dirham di Pasar Muamalah Indonesia (Adila, 2020).

Kelima, skripsi oleh Muhamad AfifSholahudin dengan judul Pasar muamalah pada pasar tradisional di Depok Jawa Barat perspektif hukum ekonomi syariah, UIN Sunan Gunung Djati Bandung, 2018. Berdasarkan hasil penelitiannya terdapat tiga aspek dan tinjauan langsung lapangan maka didapatkan tidak ada unsur muamalah yang dilanggar, maka disimpulkan boleh. Adapun para ahli ekonomi yang dihimpun beberapa pendapatnya menyatakan hal yang sama terkait kebolehannya, hanya saja perspektif pasar yang dimaksud oleh para ahli berbedabeda karena pandangan dari sisi yang berbeda. Adapun keberadaannya mampu ditinjau lebih lanjut berdasarkan aspek manfaat dan hambatan saat dipraktikkan kepada masyarakat yang lebih luas, khususnya persepsi masyarakat yang dibangun agar pelaksanaan pasar berjalan tidak melanggar beberapa norma Hukum Ekonomi Syariah (Sholahudin, 2018).

\section{METODE PENELITIAN}

Penelitian ini merupakan penelitian lapangan (field research) dengan menggunakan metode kualitatif bersifat normatif empiris dan dianalisis menggunakan analisis data secara induktif. Pada analisis ini peneliti mencoba mendekatkan dengan lapangan atau obyek yang diteliti. Analisis data penelitian ini menggunakan metode analisis secara induktif artinya peneliti dan objek yang dikaji lebih dapat membuat hubungan peneliti dan responden menjadi eksplisit, dapat dikenali dan akuntabel (Moleong, 2013). Teknik pengumpulan data menggunakan dokumentasi, participant observation (pengamanat berperanserta), dan wawancaraberbagai pihak terlibat didalamnya. Peneliti dalam menghasilkan data dan fakta adalah dengan melalui wawancara kepada beberapa pihak baik pengelola pasar mu'amalah, pedagang dan para konsumen dan juga peneliti berpartisipasi aktif dalam perdagangan dalam setiap pagelaran pasar mu'amalah tersebut.

\section{KONSEP DASAR}

Bagi penulis keberadaan Pasar Mu'amalah di tahun 2020 akhir dan 2021 awal di wilayah Wanasaba Kidul Talun Cirebon merupakan hal yang sangat menarik untuk dikaji, diikuti dan hasilnya bisa dituangkan dalam bentuk tulisan yang kemudian dimuat dalam jurnal sebagai bagian dari dakwah dalam bentuk tulisan. Ketertarikan penulis diawali dengan 
hasil penggalian para aktivis mu'amalah tentang konsep dan praktek pasar yang pernah berlaku yang kemudian bisa diejawantahkan dalam bentuk pasar yang nyata secara pisik. Kedua, banyak hal baru yang penulis dapatkan ketika meneliti pasar semacam ini, baik dimensi intelektual maupun dimensi ritual keagamaan. Ketiga, kemanfaatan yang luar biasa didapat oleh pedagang, penjual dan kalangan dhu'afa. Dimensi ekonomi tidak hanya berhenti pada kegiatan ekonomi semata, namun azas manfaat di mana yang ada di sekitar tempat di mana pasar itu berlangsung memiliki dan mendapatkan manfaat. Hal tersebut tidak ditemukan dalam kegiatan pasar yang lain.

\section{Definisi Pasar}

Pasar adalah tempat berkumpulnya pedagang dan pembeli yang melakukan transaksi barang atau jasa. Pasar merupakan sebuah mekanisme pertukaran barang dan jasa yang alamiah dan telah berlangsung sejak awal peradaban manusia. Dalam Islam pasar sangatlah penting dalam kegiatan perekonomian. Pasar sudah ada pada masa Rasulullah SAW dan Khulafaur Rasyidin dan menjadi Sunatullah yang telah di jalani selama berabad-abad (Islam dan Fajar, 2020). Definisi lain tentang Pasar merupakan unsur penting ekonomi, khususnya keberadaan pasar tradisional di mana pembeli mampu melihat langsung barang yang dijual oleh pedagang dan pedagang mampu menerima langsung uang yang diberikan oleh pembeli, lalu terjadi proses tawar menawar dan diakhiri dengan transaksi antar pihak (Sholahudin, 2018).

Ekonomi islam memandang bahwa pasar, Negara dan masyarakat berada dalam sebuah keseimbangan (iqtisad), tidak diperkenankan adanya sub-ordinat yang menimbulkan adanya salah satu pihak yang lebih dominan diantara yang lain. Dalam mekanismenya, pasar dijamin kebebasannya dalam islam. Pasar dibebaskan dalam menentukan cara-cara produksi dan harga, tidak boleh ada gangguan yang mengakibatkan terjadinya ketidakadilan ataupun ketidakseimbangan pasar. Meskipun dalam kenyataannya, sulit ditemukan pasar yang terbentuk sendiri secara adil, karena banyak terjadi distorsi pasar yang kemudian merugikan para pihak.

Pasar yang dibiarkan terbentuk sendiri tanpa adanya kendali juga seringkali menyebabkan munculnya penguasa pasar oleh para pemilik modal (capitalist), penguasa infrastruktur dan pemilik informasi. Diperlukan peran Negara didalamnya, yang dapat mengatur dan mengawasi ekonomi, memastikan kondisi dan persaingan pasar berlangsung dengan sempurna, penyebaran informasi yang merata dan terjadi keadilan ekonomi. Prinsip-prinsip mekanisme pasar islami dapat merujuk pada tulisan Muhammad dalam (Nasution, 2018), yang meliputi: (1). Ar-Ridha, yakni terjadinya transaksi yang didasarkan pada kerelaan masing-masing pihak. (2). Persaingan sehat, yakni didalam mekanisme pasar tidak terjadi penimbunan atau monopoli. (3). Kejujuran, yakni terjadinya transaksi yang mengedepankan nilai kebenaran didalamnya. (4). Keterbukaan \& Keadilan, yakni terjadinya transaksi yang dilakukan sebagaimana keadaan yang sesungguhnya.

\section{Definisi Mu'amalah}

Mu'amalah adalah saling transaksi antara kedua belah pihak atau lebih. Muamalah berarti transaksi bilateral di semua bidang kehidupan, baik itu sosial, ekonomi, politik atau spiritual. Penerapan hukum, yaitu Fiqih, berkaitan dengan Muamalah bertujuan untuk mengatur perilaku manusia di antara mereka sendiri (Erwandi Tarmidzi, 2013). Meskipun tulisan-tulisan Imam Malik, ImamSyafi' I dan At-Tabari merujuk ke Muamalah sebagai penentuan transaksi perdagangan dan operasi kredit, perlu diingat bahwa pernikahan, perceraian, warisan dan sebagainya juga merupakan Muamalah. Menjadi sunnatullah bahwa manusia harus berinteraksi dengan masyarakat dalam rangka saling tolong menolong (ta'awun) dan saling membantu antara satu dengan yang lainya. Sebagai 
makhluk sosial, manusia menerima dan memberi kepada orang lain. Ber-muamalah bertujuan untuk memenuhi kebutuhan hidup dan kehidupan dalam rangka mempertahankan kehidupan untuk mencapai kemajuan dalam hidupnya (Islam dan Fajar, 2020). Mu'amalah terbagi kepada dua macam, pertama, Mu'amalah Maliyah, yaitu transaksi komersil. Kedua, Mu'amalah Ghairu Maliyah, yaitu transaksi bukan komersil. Dengan demikian jual-beli atau tukar-menukar komoditas yang terjadi di pasar adalah bagian dari mu'malah maliyah atau transaksi komersil. Sementara transaksi bukan komersil (mua'malah ghairu maliyah) bisa dicontohkan di antaranya dengan pinjam-meminjam, akad pernikahan, ta'ziyah kematian dan lain-lain.

Dengan bergabungnya dua kata tersebut menjadi pasar mu'amalah menggunakan konsep Islamic market, yaitu konsep yang diterapkan oleh Nabi Muhammad SAW ke Pasar Madinah. Pasar Muamalah mengacu pada penerapan nilainilai syariah dan melarang keras praktik riba dalam setiap transaksi jual beli. Selain menggunakan rupiah, Pasar Muamalah juga menggunakan koin dinar dan dirham sebagai alat transaksinya. Tidak dipungut biaya pajak dan sewa tempat menjadi salah satu daya tarik Pasar Muamalah (Isnainidan Yayuli, 2021). Konteks pelaksanaanya haruslah dikondisikan dengan pemahaman dari proses penggalian-penggalian ajaran Islam yang tertuang dalam sejarah dan fiqh mu'amalah yang berbeda dengan pasar biasa yang sudah kita kenal. Konsep dan praktek pasar mu'amalah diawali dengan penggunaan lahan wakaf sebagai tempat berlangsungnya kegiatan pasar.

Kedua adanya pembagian zakat mal berupa dirham yang dibayarkan oleh para wajib zakat (aghniya) dan kajian fiqh tentang zakat mal. Prakteknya dengan memanggil mereka yang termasuk berhak menerima zakat (8 golongan) untuk diberikan penjelasan/edukasi tentang rukun zakat mal yang di dalamnya ada dinar-dirham sebagai alat bayar zakat yang dibagikan kepada mereka yang kemudian dibelanjakan di pasar mu'amalah. Dengan demikian ada sirkulasi pelaksanaan zakat dari orang kaya (muzakki), diterima oleh orang yang berhak menerima zakat (mustahik) yang kemudian dibelanjakan di pasar yang diciptakan menerima alat tukar dirham di samping rupiah yang kemudian dikenal dengan pasar mu'amalah. Keberlakuan rupiah di dalam pasar mu'amalah ini karena memang ia masuk dalam katagori fiqh realitas yang harus diterima, sementara dinar, dirham dan fulus sebagai fiqh yang punya rujukan, juga harus diterima. Islam memandang emas, perak, tembaga, gandum, garam, kurma, padi dan sejenisnya adalah uang yang bisa menjadi alat tukar barang komoditas yang disukai.

\section{PEMBAHASAN DAN DISKUSI}

\section{Pasar Di atas Lahan Wakaf}

Pengertian wakaf secara bahasa adalah menahan (al-habsu), dan secara syar'i menahan barang yang asal dan mengalirkan kemanfaatan dari keberadaannya di jalan Allah (Habsul ashli wa tasbiluts tsamroh fi sabilillah). Berdasarkan pengertian ini maka banyak yang bisa kita gali kemanfaatan dari keberadaan lahan dan tanah wakaf, di antaranya adalah untuk pasar. Memang di dalam pemahaman dan aktivitas masyarakat luas yang berkaitan dengan pemanfaatan tanah wakaf tampaknya diperuntukkan hanya untuk pembangunan masjid, madrasah, pesantren dan pekuburan. Pemahaman ini tidak salah karena mengalir pula kemanfaatan dari keberadaan tanah wakaf tersebut untuk kepentingan iman, ilmu dan keakheratan. 2 Unsur wajib dalam hal wakaf, barang yang diwakafkan dan manfaat dari barang yang diwakafkan sudah terlampaui. Namun, pemahaman terhadap wakaf dan pemanfaataannya tersebut harus diperluas menjadi pemenuhan terhadap kebutuhan jasadi (baca perut) dan keduniawiaan, salah satu penggunaannya diperuntukkan untuk pasar.

Ketika tanah wakaf diperuntukkan untuk kegiatan pasar, sama saja kita sedang 
memberikan penghormataan dan rasa nyaman bagi pedagang dan penjual untuk melakukan kegiatan transaksi komersilnya sebebas mungkin tidak lagi merasa dikejarkejar tim trantib akibat berjualan di tempat yang dilarang berjualan. Konsekwensi logis dari keberadaan pasar di atas tanah wakaf maka pedagang tidak dipungut biaya sepeserpun untuk menyewa tempat kepada pengelola dan penjualpun tidak dipungut biaya parkir bagi kendaraannya yang diparkir. Ada pedagang yang bermobil ketika membawa dagangnya, ada pula yang bermotor, begitu juga dengan pembelinya pedagang dan penjual berbagai kelaspun bisa bebas bertaransaksi.

Pasar mu'amalah yang dijadikan objek kajian oleh peneliti ini menggunakan teras dan halaman madrasah Al-Washliyah Wanasaba Kidul sebagai tempat pasar yang juga dibangun di atas tanah wakaf tiap hari Ahad dua pekan sekali. Fasilitas yang diberikan adalah teras dan halaman madrasah yang bersih, disediakan meja dan kursi untuk lapak dan pedagangnya, toilet dan masjid bisa dipakai untuk hajat pedagang dan pembeli. Tanpa dipungut biaya apapun, baik penarikan uang sewa maupun pajak. Dari pemandangan ini tampak sekali kelipatan dalam memanfaatkan tanah wakaf bisa untuk pendidikan dibangunnya madrasah dan bisa pula untuk kegiatan komersil diselenggarakannya pasar terbuka non bangunan permanen artinya tidak boleh dibangun di atasnya toko-toko.

Konsekuensi lain dari pelaksanaan pasar di atas tanah wakaf bagi para pedagang adalah mereka tidak boleh memastikan bahwa lapak yang biasa mereka tempati adalah hak paten mereka, ketika datang terlambat waktu pasar mu'amalah buka dan tempatnya sudah dipakai oleh pedagang lain, maka tidak boleh protes apalagi sampai merebut tempat tersebut. Karena pasar tersebut merupakan shodaqoh tanpa kepemilikan pribadi. Ia harus mengambil tempat yang belum ditempati oleh pedagang lain. Sebagaimana seorang makmum sholat tidak boleh mengklaim shaf yang biasa ditempati menjadi miliknya untuk selamanya ditempati dalam sholat berjama'ah, bila ia telat dan sudah ditempati oleh makmum yang lain maka ia harus mencari shaf lain.

Seorang makmum sholat berjama'ah juga tidak boleh membawa barang yang haram dan najis ke dalam masjid, begitu juga pedagang dalam pasar mu'amalah tidak boleh membawa dan memperjualbelikan barang haram dan najis. Ketika adzan berkumandang seluruh pedagang dan pembeli sejenak untuk meninggalkan transaksi perdagangannya dan segera memenuhi panggilan adzan untuk melakukan sholat berjama'ah. Dalam kasus Pasar Mu'amalah yang penulis teliti, Pasar Mu'amalah dibuka pada pagi hari jam 8 di hari Ahad pekan kedua hingga jam 12:00/adzan sholat dhuhur berkumandang, segenap pedagang bergegas untuk menunaikan sholat secara berjama'ah dan setelah selesai sholat, ada pedagang yang melanjutkan dagangnya, ada pula yang langsung pamitan pulang ke daerah masingmasing, ada yang ke Kuningan, ke Majalengka, ke Cirebon kota dan sebagian besar ke daerah Talun dan sekitarnya. Dengan penjelasan demikian, tampaknya amaliyah sunnah di masjid berlaku juga di pasar (Zaim Saidi, 2011).

Bagi peneliti yang juga ikut berjualan dalam pasar mu'amalah mendapatkan beberapa keuntungan, menambah pertemanan dan jalinan silaturrahmi sesama pedagang, barter komoditas antar pedagang berdasarkan keridhoan, mendapatkan fasilitas untuk mengenalkan produk yang didagangkan hingga naiknya omset penjualan tanpa harus keluar uang sewa kecuali infaq seikhlasnya, namun yang terakhir ini belum diberlakukan. Perasaan yang sama juga dirasakan oleh para pedagang dan pembeli yang menggunakan fasilitas pasar mu'amalah, surplus bagi penjual dan kemanfaatan bagi pembeli. Dengan demikian perdagangan adalah aktivitas produktif menghasilkan surplus dan kemanfaatan, sekaligus menggerakkan harta dari satu tangan ke tangan lainnya. 
Penggunaan tanah wakaf untuk pasar adalah salah satu solusi dari ajaran Islam bagi pemberdayaan ekonomi masyarakat kecil pedesaan. Di samping untuk pasar dalam pemenuhan kebutuhan jasadi manusia dan keduniawiaan, tanah wakaf bisa juga digunakan untuk membangun tempat-tempat komersial lainnya, seperti kios, kolam ikan, kebun, hotel, pusat-pusat perbelanjaan, rumah sakit, pergudangan dan lain sebagainya yang keuntungannya bisa dirasakan oleh masyarakat yang kurang mampu secara langsung setelah dipotong pemeliharaan dan gaji karyawan. Dengan demikian tanah wakaf tidak lagi menjadi beban bagi para nadzir tapi sudah menjadi asset yang menguntungkan. Nadzir mampu mengelola asset wakaf dan menghasilkan surplus darinya. (Zaim Saidi, 2012).

Ada satu contoh atau model tanah wakaf tidak lagi menjadi beban tapi sudah menjadi asset yang menguntungkan. Hal ini yang telah dilakukan oleh pengurus AlWashliyah Cirebon dalam menghidupkan tanah wakaf yang selama ini kurang diberdayakan. Dalam menghidupkan tanah wakaf, jelas diperlukan dana segar. Oleh karena itu pengurus Al-Washliyah mengeluarkan program kerja wakaf tunai produktif yang ditujukan kepada guru dan karyawan Al-Washliyah, seikhlasnya mengisi nominal berapa yang akan disetorkan tiap bulannya.

Program tersebut berhasil digulirkan dengan berdirinya kios wakaf, balong wakaf dan kebun wakaf di atas tanah wakaf dan dibangun oleh wakaf tunai yang dikumpulkan tersebut. Uang sewa dari barang tersebut bisa dinikmati oleh anakanak yatim, para guru-karyawan, ustadzustadzah Madrasah DTA, memberi ongkos musafir yang kehabisan ongkos, memperbaiki genteng madrasah yang bocor dan ikut membantu pembangunan ruang belajar madrasah ketika murid-muridnya sudah melebihi kapasitas ruang yang ada. Tampak sekali surplus yang bisa digunakan untuk pengamanan dan jaminan sosial. Kegiatan wakaf tunai produktif hingga tulisan ini dibuat masih istiqomah dilakukan dan mencita-citakan terbangunnya beberapa rumah kontrakan wakaf di tanah wakaf yang masih ada bila nominalnya sudah mencukupi. Hasil keuntungan sewanya kelak akan digunakan untuk kegiatan pengamanan dan jaminan sosial. Dengan demikian tercapailah target memelihara asset wakaf dan menikmati hasil dari wakaf, "memelihara itiknya, menikmati telurnya".

Kegiatan pasar mu'amalah diatas, sejalan dengan hasil penelitian di Emfa pasar mu'amalah Yogyakarta bahwa model usaha pasar muamalah Dinar dan Dirham dilakukan dengan konsep tanpa sewa tempat, sehingga tidak ada klaim tempat (booking). Pedagang hanya dikenakan infak yang digunakan untuk biaya operasional pasar seperti air, listrik, dan lain-lain. Penerapan prinsip-prinsip muamalah di pasar mu'amalah dengan menerapkan beberapa disiplin jual beli yang sesuai syariat Islam seperti tidak terjadi jahalah, al-ikrah, gharar, dharar, dan lainlain. Pengawasan internal dilakukan pihak pengelola dengan melakukan ceramah tentang cara berdagang yang sesuai sunnah Rasulullah serta menyampaikan berbagai informasi seperti tata tertib berjualan di WA grup. Pengawasan eksternal dilakukan dengan memberikan sanksi kepada pedagang yang menolak pembayaran menggunakan dirham maupun dinar berupa peringatan hingga larangan untuk berjualan di pasar tersebut (Gantoro, 2020).

Hal tersebut hendaknya menjadi pembelajaran bagi para aghniya untuk menshodaqoh jariyahkan hartanya untuk kepentingan pemberdayaan wakaf berdimensi pemenuhan kebutuhan jasadi masyarakat luas yang kurang mampu di samping kebutuhan ukhrowi, keduanya sama baiknya, sama pahalanya dan sama manfaatnya, sehingga kesejahteraan dunia dan akhirat bisa dicapai secara sinergitas, berkordinasi dan bahu-membahu untuk mencapainya melalui optimalisasi pemberdayaan dan kemanfaatan tanah wakaf. 


\section{Rekonstruksi Penggunaan Dirham dan Fulus Sebagai Alat Tukar}

Kaitan yang kedua dengan pasar mu'amalah adalah Dirham (koin perak) dan Fulus (koin tembaga) sebagai alat tukar selain rupiah dan barter antar komoditas yang diperdagangkan berdasarkan keridhoan masing-masing pihak yang berkepentingan. Sehari sebelum diadakan pasar mu'amalah, penanggung jawab dari pelaksanaan kegiatan tersebut membagikan kepingan dirham 30-40 buah kepada fakir miskin sekitar pasar yang sudah didata sebelumnya, perorang dapat 1 Dirham yang kalau dirupiahkan menjadi 73.500 untuk dibelanjakan esok hari di pasar mu'amalah sesuka hatinya sesuai dengan kurs tadi bila belanjaannya melebihi maka ia harus merogoh koceknya sendiri. Dirhamdirham tersebut didapat dari zakat maal yang dibayarkan para aghniya. Tidak kurang dari 15 orang pedagang yang sudah mendaftarkan diri tiap 2 pekannya dan siap menerima Dirham, Fulus dan barter dalam bertransaksi di pasar mu'amalah. Beragam komoditas yang diperdagangkan dari mulia kue-kue ringan khas Cirebon, produk-produk herbal, bumbu masak, sembako, minuman dingin, pakaian dan lain sebagainya.

Selain itu, penanggung jawab juga mempersilahkan masyarakat sekitar yang mempunyai banyak beras dan menginginkan komoditas lainnya tapi minim mempunyai rupiah boleh dibawa dan ditukarkan dengan komoditas lainnya berdasarkan keridhoan dan rupiah sebagai barometernya. Hal itu adalah sebuah kemanfaatan lain dari sekian manfaat yang sudah disebutkan sebelumnya di pasar mu'amalah.Menurut peneliti adanya disparitas cara menukarkan barang tidaklah menggugurkan rutinitas rupiah karena barometer dan mendapatkannya pun harus ditukar dengan rupiah.

Dinar (koin emas), dirham dan fulus tidaklah murni kreasi umat Islam, sentuhan peradaban-peradaban sebelum Islam telah menghiasi perjalanan sejarah keberadaan dan keberlakuan koin-koin tersebut sebagai alat tukar perdagangan sesuai dengan kadar dan fungsinya. Dinar adalah sebutan untuk satuan berat bagi koin emas yang beratnya 4,2 / 4,7 dan 4,9 gram emas tercetak di masa Romawi. Ketika Rasulullah berdakwah di Makkah dan Madinah semasa dengan akhir-akhir masa kejayaan Romawi, maka secara sosiologis Dinar versi Romawi berlaku dan digunakan sebagai alat tukar dan alat bayar dalam transaksi perdagangan untuk komoditas mahal di Jazirah Arab, sementara Dirham adalah sebutan untuk satuan berat koin perak yang beratnya 3,5-4.0 gram tercetak di masa Persia. Ketika Rasulullah berdakwah di Makkah dan Madinah di akhir-akhir masa kejayaan Persia menggunakan Dirham Persia sebagai alat tukar dan alat bayar dalam transaksi perdagangan untuk komoditas menengah. (Abdullah, 2020).

Nilai mata uang dinar dan dirham masih sangat relevan dengan sekarang ini, terbukti fakta sejarah tentang uang yang berbasis logam mulia (emas dan perak) yang kebal terhadap inflasi, juga mengukur tingkat persaingan dan respon pasar ketika kedua mata uang ini digunakan di pasar global. Adanya pasar mu'amalah mulai mengeliatkan kembali dinar pada abad 21 ini. Dinar berasal dari Bizantium sedangkan dirham dari Sasanian dan Fals dari Yunani. Ketetapan terakhir menurut Umar Bin Khatab, berat Dinar adalah 4,25 gram sedangkan dirham adalah 3 gram. Persoalan bentuk, nama, corak, dan design fisiknya adalah aksesoris semata, yang terpenting penentuan nilai mata uang atau dinar intrinsiknya sendiri (Yunus dan Dede R, 2016).

Menurut peneliti, penerimaan Rasulullah dan umat Islam di awal risalah terhadap Dinar Romawi dan Dirham Persia secara ekonomis dan politis mencerminkan pengakuan terhadap nilai intrinsik, keajegan nilai dan hegemoni kedua kerajaan super power dunia yang kelak di masa Khalifah Umar bin Khottob dan Abdul Malik bin Marwan dari dinasti Umayyah dirham dan dinar versi Islam yang secara politissosiologis tidak lagi mengakui hegemoni kedua kerajaan tersebut. Sebagaimana kita hidup di masa kini secara sosiologis 
mengakui hegemoni dolar. Adapun fulus adalah sebutan untuk koin tembaga atau uang receh yang digunakan untuk transaksi komoditas dengan harga murah-meriah.

Dalam asar mu'amalah kali ini penulis temukan hanya dirham dan fulus yang beredar sebagai alat tukar dalam bertransaksi, belum ditemukan dinar, kemungkinan sekali karena harganya yang tinggi mencapai 3,8 juta per 1 Dinar. Biasanya digunakan untuk penukaran 1-2 kambing. Nilai tersebut sudah berlaku sejak zaman Nabi hingga sekarang. Pernah terjadi di pasar mu'amalah di tempat lain penawaran motor dan mobil ditukar dengan beberapa keping dinar. Dari paparan singkat ini tampak sederhana sekali merekonstruksi penggunaan dirham dan fulus sebagai alat tukar sesama komoditas yang berharga dan tidak ada yang dirugikan.

Pengenalan Dinar dan Dirham untuk pertama kalinya bagi peneliti, ketika di bulan Desember 2010. Selama tiga hari 22-24 Desember 2010 yang lalu berbekal informasi dari majalah Hidayatullah menyempatkan diri melakukan penelitian singkat guna mengetahui dari dekat proses akad tukarmenukar barang dengan menggunakan uang koin emas dan perak. Daerah tersebut adalah jln, Sungai Landak Kampung Nelayan Cilincing Jakarta Utara dan Komplek Masjid Al-Azhar.

Kedua daerah yang disebutkan pertama, oleh para pegiat Dinar-Dirham di Indonesia dijadikan model dan zona wisata diberlakukannya dalam proses tukarmenukar komoditas mereka. Di zona tersebut terdapat 70 pedagang kecil yang sudah faham dan terbiasa menggunakan Dinar-Dirham dalam transaksi usahanya. Sementara itu, di komplek Masjid Al-Azhar diadakan hari pasaran Dinar-Dirham. Sebuah pasar yang sengaja diciptakan untuk melakukan sosialiasi penggunaan Dinar-Dirham dalam transaksi jual-beli kepada masyarakat luas lengkap dengan outlet/tempat penukaran mata uang rupiah ke Dinar-Dirham sebagai uang resmi atau yang berlaku di hari pasaran tersebut. Penelitian ini dilakukan oleh peneliti karena didorong oleh rasa ingin tahu yang mendalam tentang bentuk fisik dari Dinar, Dirham dan Fulus serta penggunaannya, yang selama ini penulis tahu hanya melalui buku-buku sejarah yang kemudian diajarkan kepada mahasiswa. Ketika peneliti mendapatkan Dinar dan Dirham dalam bentuk fisiknya yang kontemporer dan mengerti akan kegunaannya maka semakin meningkat kepercayaan diri penulis untuk menyampaikan hal tersebut kepada mahasiswa.

Beberapa alasan yang patut diperhatikan, bahwa para pedagang dan pembeli yang bertemu di pasar mu'amalah itu dipengaruhi tiga variabel terhadap penggunaan dinar dan dirham sebagai alat transaksi yaitu faktor tingkat lingkungan sosial, tingkat religiusitas dan tingkat kepercayaan pada otoritas penerbit dalam hal ini wakalah dan sejenisnya (Adila, 2020).

Dalam lintasan sejarah Dinar, Dirham dan Fulus jauh sebelum Islam, kemunculannya sebagai sistem ekonomi dunia telah dikenal sejak 4000 tahun yang lalu sebelum masehi. Hal ini ditandai dengan penemuan emas dalam bentuk kepingan di Spanyol. Dalam sejarah lain disebutkan bahwa emas ditemukan masyarakat Mesir Kuno (Circa) 3000 tahun sebelum masehi. Dimulainya logam tersebut sebagai sistem uang menurut satu versi sejarah 2800 tahun yang lalu dilaksanakan untuk pertama kalinya oleh Kerajaan Lydia, yang berlokasi sekarang di negara Turki. Koin yang berlaku saat itu terbuat dari campuran emas murni dan perak dengan komposisi $40 \%$ emas dan $45 \%$ perak yang dilapisi tembaga. Kemudian mengalami proses peleburan, penguatan dan dibentuk sesuai dengan selera mereka yang masih sederhana (Masduqi, 2012).

Setelah kerajaan Lydia, disusul oleh China dalam menjadikan emas dan perak sebagai mata uang. Bangsa lain yang juga menggunakan emas dan perak sebagai sistem alat tukar adalah bangsa Persia dan Romawi. Para ahli mata uang menyatakan bahwa bentuk-bentuk mata uang tersebut sebagai 
barang koleksi, antik, unik dan berlaku sebagai alat tukar dalam bertransaksi di masanya. Oleh karenanya fungsi ekonomi telah sukses diperankan oleh mata uang-mata uang primitif tersebut.

Proses politik dan sejarah telah mengubah perimbangan peradaban dengan segala implikasinya. Ketika menjelang Islam hadir, ada dua peradaban yang pernah berjaya dan menjadi super powernya dunia saat itu, Romawi dan Persia, namun kemudian mengalami keterpurukan lalu digantikan dengan peradaban yang lebih fresh dan manusiawi, yaitu Islam.

Sebagaimana yang telah dijelaskan di muka, bahwa mata uang emas Dinar dan perak Dirham merupakan warisan dari peradaban Romawi Timur (Bizantium) dan Persia (Yezdigird Sassanian III) yang kemudian dalam perjalanan waktu penggunaannya pada masa peradaban Islam melalui ketetapan dan keputusan Rasulullah yang dilanjutkan oleh Khalifah Umar bin Khattab.

Ketetapan dan keputusan Rasulullah tentang Dinar, Dirham dan Fulus tidak saja berhenti sebagai alat tukar yang syah dalam jual-beli dan tukar-menukar (akitvitas ekonomi dan perdagangan), melainkan lebih jauh dari itu sebagai komponen penting dalam membayar zakat mal, sedekah dan dapat digunakan pula sebagai mahar. Perubahan yang signifikan juga terjadi pada satuan berat standar Dinar yang diukur dengan 22 karat emas $91,7 \%$ dengan berat 4,25 gram, berdiameter $23 \mathrm{~mm}$, sementara Dirham terbuat dari perak murni seberat 2,975 gram, berdiameter $25 \mathrm{~mm}$. Kedua kerajaan tersebut menjadi sentral dalam bidang kemiliteran dan perekonomian pada jamannya (Fatma Khalieda, 2017).

\section{Uang dan Barang sebagai Alat Tukar dalam Persfektif Islam}

Uang adalah standar kegunaan yang terdapat pada barang dan tenaga. Oleh karena itu, uang didefinisikan sebagai sesuatu yang dipergunakan untuk mengukur tiap barang dan tenaga. Kasus lain misalnya harga adalah standar untuk barang, sedangkan upah adalah standar untuk tenaga manusia, yang masingmasing merupakan perkiraan masyarakat terhadap nilai barang dan tenaga manusia. Sementara promis, saham dan sejenisnya tidak bisa disebut uang. Perkiraan nilai-nilai barang dan jasa ini di negeri manapun dinyatakan dengan satuan-satuan, maka satuan inilah yang menjadi standar yang dipergunakan untuk mengukur kegunaan barang dan jasa/tenaga. Satuan-satuan inilah yang menjadi alat tukar (Medium of Change). Satuan-satuan inilah yang disebut dengan uang (Abdullah, 2020).

Ketika menetapkan hukum-hukum tentang jual beli dan persewaan, Islam tidak menentukan barang tertentu yang menjadi pijakan pertukaran untuk menukarkan barang atau tenaga dengan kegunaan tertentu sebagai suatu keharusan. Namun, Islam memberikan kebebasan kepada manusia untuk melakukan pertukaran dengan barang apa saja, selama masing-masing menerima. Seseorang boleh menikahi seorang wanita dengan kompensasi mengajari al-Qur'an kepada seorang wanita tersebut hingga bisa. Seseorang juga boleh membeli barang dengan kompensasi bekerja kepada pemiliknya selama sehari, misalnya. Seseorang juga boleh bekerja kepada seseorang selama sehari dengan kompensasi berupa sejumlah kurma.

Dalam banyak hadits Rasulullah Shallallahu 'Alaihi wa Sallam, secara lebih rinci menegaskan dijaminnya kebebasan bertransaksi ini. Ia mengindikasikan enam benda niaga sebagai alat tukar, yaitu emas, perak, tepung, gandum, korma dan garam. Tetapi, kalau di Indonesia para pemilik sawah lazim membayar upah para pemanen padinya dengan gabah, dan transaksi ini diterima oleh kedua belah pihak, maka gabah adalah sebagai alat tukar yang syah. (Zaim Saidi, 2011).

Sistem alat tukar ini, sejalan dengan konsep roda ekonomi Islam dengan penggerak kembalinya mata uang dinar (emas) dan dirham (perak) sebagai sistem keuangan yang bebas riba, nilai keadilan dan 
untuk kesejahteraan umat, dan banyak instrumen lainnya seperti; zakat, wakaf, sedekah, Infaq. Roda ekonomi Islam yang berkaitan salah satunya antara pembiayaan bebas riba, pasar yang syar'i, harta yang berputar dan uang yang adil dapat digambarkan sebagai berikut (Haerisma, 2011):

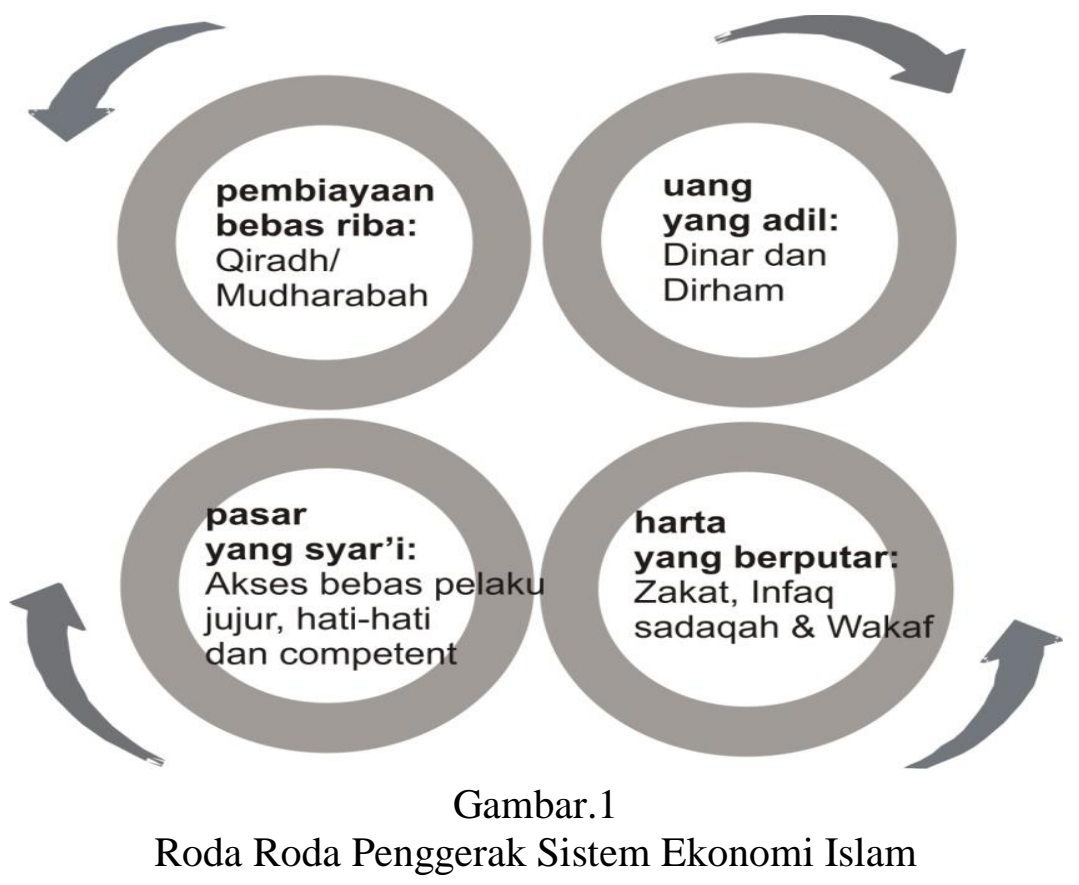

Demikianlah, Islam memberikan kebebasan kepada manusia untuk melakukan pertukaran dengan mempergunakan barang apa saja yang dia sukai. Hanya saja, pertukaran barang dengan satuan tertentu itu telah ditunjukkan oleh Islam, di mana Islam telah menunjukkan satuan uang tersebut. Bahkan, Islam telah menentukan satuan tersebut untuk kaum Muslimin dalam bentuk uang khas, yaitu emas dan perak. Penggunaan emas dan perak menunjukan bahwa ada standar harga yang ditentukan, artinya Islam tidak menyerahkan kepada masyarakat untuk menyatakan perkiraannya terhadap standar kegunaan barang atau tenaga dengan satuan-satuan yang tetap, atau yang berubah dan bisa ditukar-tukar sesuka hatinya.

Selain mengindikasikan jenis benda niaga yang dapat digunakan sebagai alat tukar, yang dicirikan dengan sifat alamiahyakni daya simpannya yang panjang, dapat distandarisasikan, dipecah dalam satuan berat dan volume yang konkrit. Rasulullah juga menyebutkan rukun lain dalam transaksi setelah 'suka sama suka' adalah dari 'tangan ke tangan' atau kontan. Suatu transaksi yang tidak kontan belum syah sebagai jual-beli, melainkan sebagai transaksi utang-piutang, yang tidak boleh mengandung unsure tambahan. Tambahan dalam transaksi utang piutang merupakan riba.

Rukun ketiga yang harus dipenuhi dalam transaksi (yang melibatkan barang niaga, dan bukan melibatkan layanan jasa) adalah kesetaraan nilai barang yang ditransaksikan, mitslan bi mitslin. Dimaknai dengan emas dengan emas, perak dengan perak, tepung dengan tepung, kurma dengan kurma, garam dengan garam, atau barang lainya sebagai pertukaran karena bendanya sejenis. Syaratnya dalam transaksinya adalah selain kontan, harus sama takaran dan timbangannya. Bilamana bendanya yang dijual belikan tak sejenis boleh tidak setara, 
asal suka sama suka dan kontan. Dengan transaksi kontan nilai nilai yang membuat transaksi menjadi tidak baik bias dihindari.

Beberapa kaidah hukum di atas sekaligus menunjukkan kepada kita bahwa, (1) benda-benda yang ditunjukkan dalam hadits adalah alat tukar (uang), (2) bahwa alat tukar yang boleh digunakan dalam transaksi (bukan cuma perdagangan barang niaga tetapi juga termasuk layanan jasa) harus memiliki nilai intrinsik, hingga rukun 'sama takaran dan timbangannya' dapat dipenuhi. Jelaslah kepada kita bahwa uang atau alat tukar menurut syariat Islam harus berbentuk a'in.

Penggunaan dinar, dirham dan fulus serta kegiatan pasar mu'amalah kini tidak lagi dipandang sebagai hal yang melanggar hukum positif, setelah dikeluarkannya putusan Pengadilan Negeri Depok No. 202/Pid.Sus/2021/PN DPK setelah sempat dipermasalahkan hingga ditahannya konseptor dan kreatornya, Zaim Saidi. Lebih lengkapnya putusan tersebut sebagai berikut : 1. Menyatakan terdakwa Zaim Saidi tidak terbukti secara sah dan meyakinkan bersalah melakukan tindak pidana sebagaiamana dakwaan pertama dan kedua. 2. Membebaskan terdakwa Zaim Saidi dari semua dakwaan penuntut umum. 3. Memenrintahkan agar terdakwa dibebaskan dari tahanan segera setelah putusan ini diucapakan. 4. Memulihkan hak-hak terdakwa dalam kemampuan, kedudukan dan harkat serta martabatnya. 5. Mengembalikan semua barang bukti kepada terdakwa. 6 . Membebankan biaya perkara ini kepada Negara. Dengan dikeluarkan putusan pengadilan ini maka tidak ada keraguan dan kekhawatiran lagi bagi siapapun yang akan menggunakan dinar, dirham dan fulus sebagai alat transaksi di dalam pasar mu'amalah maupun di luar pasar mu'amalah.

\section{KESIMPULAN}

Konsep dan praktek transaksi dinar, dirham dan fulum merupakankeberhasilan Rasulullah dan para sahabatnya dalam menciptakan kemandirian dan kemapanan dalam bidang ekonomi tak lepas dari nilai dan ajaran Islam itu sendiri, yang mengajarkan dan mengatur sistem keuangan dan perdagangan (dengan salah satunya melihat pasar) yang bebas dan berkeadilan.

Pasar yang dibangun pada masa Madinah seperti halnya masjid yang dibangun kaum muslimin di atas tanah wakaf. Ketika memasuki masjid tanpa pungutan apa-apa, tidak ada "pembokingan" tempat untuk mengutamakan satu orang diatas orang lain, serta tidak ada barang haram. Tambahan buat pasar alat tukarmenukarnya bisa menggunakan dinar, dirham dan fulus sebuah alat tukar yang berkeadilan yang Islam ajarkan kepada pemeluknya.

Keberadaan pasar mu'amalah sangat dirasakan kemanfaatanya baik para pedagang maupun pembeli. Hal ini dikarenakan pedagang tidak dikenakan biaya sewa, retribusi apapun untuk kelancaran transaksi di pasar tersebut. Gairah perdagangan kaum muslimin melalui pasar seperti yang dijelaskan di atas terus bergerak seiring dengan semakin meluasnya jangkauan dakwah Islam termasuk ke wilayah Nusantara.

Nusantara yang bermakna gugusan pulau-pulau memiliki potensi alam yang sarat aliran sungai, selat bahkan luasnya lautan menjadi modal tersendiri bagi berseminya Islam dan nilai-nilai Islam yang berkaitan dengan keuangan dan perdagangan. Karena laut dan sungai salah satu media transportasi untuk menjangkau daerah daerah dimana ekonomi tumbuh dan berkembang.

Institusi wakaf menjadi faktor penentu bagi keberlangsungan pasar mu'malah. Karena pasar mu'amalah berlangsung $\mathrm{di}$ atas tanah wakaf yang bertujuan untuk mengembangkan fungsi wakaf itu sendiri. Pemahaman selama ini bahwa wakaf terfokus pada masjid, pesantren, madrasah dan kuburan. Dengan demikian, perjalanan pasar mu'amalah bisa menghadirkan manfaat bagi pedagang, pembeli dan masyarakat sekitar dalam 
mensosialisasikan alat transaksi dinar, dirham dan fulus.

\section{DAFTAR PUSTAKA}

Abdullah, Adam. (2020). The Islamic Monetary Standard: The Dinar and Dirham. International Journal of Islamic Economics and Finance Studies, 1, 1-29, doi: 10.25272/ijisef.659330.

Adila, Nispi Amalia. (2020). Penggunaan Dinar dan Dirham Sebagai Alat Transaksaksi di Pasar Muamalah Indonesia: Analisis Pengaruh Faktor Sosial, Faktor Kecemasan, Faktor Religiositas, dan Faktor Kepercayaan. Thesis, Universitas Pendidikan Indonesia.

Gantoro, Danang Handir. (2020). Model Usaha Pasar Muamalah Dinar dan Dirham di Yogyakarta. Thesis, Universitas Islam Indonesia, Yogyakarta.

Haerisma, Alvien Septian. (2011). Dinar dan Dirham (Studi Perkembangan dan Penerapan). Cirebon: Eduvision Publishing.

Haerisma, Alvien Septian. (2011). Model Transaksi Dinar dan Dirham Dalam Konteks Kekinian. Holistik, 12 (2), 115136.

Islam, Bintang dan Muhamad Fajar. (2020). Perancangan Infografis Pasar Muamalah Sebagai Awal Kembalinya Dinar Dirham. Visual Heritage: Jurnal Kreasi Seni dan Budaya, 3(1), 53-59.

Isnaini, Anif Nur dan Yayuli. (2021). Penerapan Konsep Pasar Islam Era Rasulullah Perspektif Zaim Saidi (Studi Pasar Muamalah Surakarta). Thesis, Universitas Muhammadiyah Surakarta.

Khalieda, Fatma. (2017). Isu-Isu Dinar dan Dirham. Jurnal AL-INTAJ, 3 (1), 85101.

Masduqi, Zaenal (2012). "Mengembalikan Perdagangan Islam yang Berkeadilan: Sebuah Antitesa Terhadap Perdagangan Kapitalisme Global". Paper dipresentasikan dalam acara Conference Proceedings: Annual International
Conference on Islamic Studies (AICIS) XII di Universitas Islam Negeri Sunan Ampel Surabaya, 5 - 8 November 2012, 837.

Masduqi, Zaenal. (2015). Dari Palestina Hingga Kawasan Gronggong "Persembahanku Untuk Umat". Cirebon : Elsi Pro.

Moleong, Lexy J. (2013). Metodologi Penelitian Kualitatif. Bandung: PT. Remaja Rosdakarya.

Nasution, Adanan Murroh. (2018). Konsep Pasar Yang Islami. Jurnal Al-Maqasid, 4(2). Juli-Desember. 126-144.

Saidi, Zaim. (2012). Stop Wakaf Dengan Cara Kapitalis. Depok: Delokomotif.

Saidi, Zaim. (2012). Euforia Emas, Mengupas Kekeliruan Dan Cara Yang Benar PengembanganDinar, Dirham Dan Fulus Agar Sesuai Al-Qur'an dan As-Sunnah. Depok: Pustaka Adina.

Saidi, Zaim. (2011), Rabi'uts Tsani 1432/April). Dinar Dirham Dilindungi UUD 1945, Buletin Mu'amalah (1).

Tarmizi, Erwandi. (2013). Harta Haram Muamalat Kontemporer. Bogor: PT. Berkat Mulia Insani.

Yunus dan Dede R. (2016). Islamic Law of Monetary Economics: Evidence from Dinar and Dirham. International Journal of Economic Perspectives, 10 (4), 346353. 